\title{
Job Satisfaction Dominates The Influence of Leadership and Work Environment on Work Spirit
}

\author{
Agung Nufrizal $^{1}$, Tanto Gatot Sumarsono ${ }^{2}$, Harsono $^{3}$ \\ ${ }^{1}$ Master of Management Program, University of Merdeka Malang, Indonesia \\ ${ }^{2,3}$ Faculty of Economics and Business, University of Merdeka Malang, Indonesia
}

\begin{abstract}
This study aims to determine the effect of the leadership, work environment and job satisfaction on employee work spirit Company dolphin Malang chips, and to analyze the variables that affect the dominant of the leadership, work environment, and job satisfaction on employee work spirit Company dolphin Malang chips. Respondents in this study were all employees Dolphins Chips Company Malang. The population in this study was 125 employees; the data collection method used was census by using the entire amount of the population as a sample. Engineering analysis using descriptive analysis, test classic assumptions and hypothesis testing completed using multiple linear regression techniques with SPSS statistical calculators. The results show that leadership, work environment, and job satisfaction effect on employee work spirit dolphin Chip Company Malang, and job satisfaction dominant influence on employee work spirit dolphin Chip Company Malang. This suggests that the main priorities that should be considered to improve employee work spirit are job satisfaction in the organization and management refer to indicators such as job descriptions on companies that are very clear.
\end{abstract}

Keywords: Leadership, Work Environment, Job Satisfaction, Work Spirit.

\section{INTRODUCTION}

The existence of human resources is seen as a crucial element in the process of organizational development. The development organization will be achieved if supported by qualified human resources. The quality of human resources can be fulfilled if one of them work spirit. Employee work spirit can be seen from the level of absenteeism. Work spirit is a reflection of the attitude of the employee or group attitudes toward work and cooperation. If employees seem happy, optimistic about the activities and tasks, as well as the friendly one with the other, then the employee was said to have a high spirit. Conversely, if the employees seem disgruntled, irritability, frequent illness, cantankerous, nervous and pessimistic, then the reaction is said to be evidence of low work spirit.

The leader holds a very important role in managing and implementing the company's strategy. The success rate can be determined by the leadership of employees in the company, namely by looking at the style of leadership that we run.

A pleasant working environment a dream for all employees in a company or organization. A good working environment will make employees work in pleasant conditions or excited and it will cause the job can be resolved satisfactorily and on time.

In general, work spirit appears because employee satisfaction is claimed is composed of material and non-material. The creation of employee satisfaction will improve the effectiveness of performance and success in work. Employee satisfaction asked to be created as well as support for the working spirit, love of work, work discipline, performance, increasing employee performance, support, support, raising employment in accordance with the request of the company. Anyone can enjoy the work while doing work as closely as possible to complete its work and increase productivity and performance [1].

Robbins dan Judge states that a person who felt job satisfaction higher will show a positive attitude towards work such as productivity or higher performance, commitment to high-level organization, job stress high level, the behavior of a high level, and what to do, such as productivity or high performance, high organizational commitment to the organization, a high level of work stress, high-level behavior, and what should be supported [2]. Employees who have a high level of job satisfaction have a positive effect on increasing job satisfaction. Results of Simamora et al. and Rehatta showed that job satisfaction is proven to work well [3, $4]$.

By As'ad, research on breast satisfaction often do. However, the problem of employee satisfaction remains important because it has been proven beneficial in improving employee attitudes and behavior that would benefit the company [5]. The job itself is the view of employees on the job. Following suitability skilled jobs that employees can encourage employees to produce a good performance and increase job satisfaction. Payroll system is also tailored to the skill level of employees, when the 
opportunities provided by the company are lower than those applied to similar companies can lead to employee dissatisfaction with pay. As well as with colleagues who are a source of job satisfaction for individual employees. The working group with a high degree of proximity tends to cause employees to be more satisfied in the working group. Promotion has a different effect on job satisfaction. Promotion will provide opportunities for personal growth, more responsibility, and increased social status. When the campaign carried out in a fair, expected to provide employee satisfaction to employees [6].

\section{THEORITICAL REVIEW}

\subsection{Work spirit}

Work spirit will stimulate someone to be able to work and creativity in his work. Employees who have high work spirit must be able to complete its work effectively and efficiently. Work spirit according Nitisemito is doing the job harder, thus would be expected to work faster and better [7]. Based on the above definition can be concluded that work spirit is a mirror and conditions of employees in the work environment. If work spirit increases, companies will gain many advantages such as low levels of absenteeism, little labor turnover, work more quickly resolved and so on, so that the level of labor productivity can be improved. While indicators of work spirit by Moekijat consisting of: Joy, cooperation, pride in service, Adherence to the obligations, Loyalty [8]. Further indicators of work spirit by Nitisemito, Employee work spirit tend to carry out tasks according to time, do not delay work on purpose, as well as speed up the work, the low attendance rate, Labor turnover, reduced anxiety [7].

\subsection{Leadership}

Leadership by Rival and Mulyadi is the ability of a leader to influence others to provoke positive feelings in those they lead to achieving the desired objectives [8]. Leadership indicators include: The ability to foster cooperation and good relations, ability effectiveness, participatory leadership, ability to delegate tasks or time, ability to delegate tasks or authority.

\subsection{Work environment}

The work environment is a condition that is around a working environment that influence the activities of employees in doing his job. Sedarmayanti defines the work environment is as follows: the environment is a strategic planning process that is used to monitor the environmental sector in determining the opportunities / threats to the organization / company. Environmental Indicators work includes: physical work environment and work environment is non-physical [9]. Robbin dan Judge states that a person who felt job satisfaction higher will show a positive attitude towards work such as productivity or higher performance, commitment to high-level organization, job stress high level, the behavior of a high level, and what to do, such as productivity or high performance [2].

\subsection{Job satisfaction}

Rivai defines job satisfaction as an evaluation that describes someone as feeling happy or unhappy, satisfied or not work satisfied [10]. Indicator job satisfaction, among others: Contents of work, supervision, organization and management, opportunities to advance, Salary and financial benefits such as incentives, co-workers, working condition.

\subsection{Formulation of hypotheses}

H1. Allegedly leadership, work environment and job satisfaction significant influence against the work spirit of the Dolphins Chips Company Malang.

Research results Priatna and Ferdiansyah, and Tarlis proved that the leadership effect on work spirit [11, 12]. Work environment provides security and allows employees to be able to work optimally. The work environment can influence the emotions of employees. If an employee enjoys working environment in which he works, then the employee will feel at home in the workplace to perform the activity so that the working time is used effectively and optimistic job performance of employees is also high. The work environment includes working relationship formed between fellow employees and working relationships between subordinates and superiors as well as the physical environment where employees work. The research result Anwar, Dwijayanto and Nurbudiyani proved that the work environment influence on work spirit $[13,14,15]$. Anyone can enjoy the work while doing work as closely as possible to complete its work and increase productivity and performance [1]. Robbins dan Judge states that a person who felt job satisfaction higher will show a positive attitude towards work such as productivity or higher performance, commitment to high-level organization, job stress high level, the behavior of a high level, and what to do, such as productivity or high performance, high organizational commitment to the organization, a high level of work stress, high-level behavior, and what should be supported [2]. Results of Simamora et al. and Rehatta showed that job satisfaction is proven to work well [13, 4]. 
H2. Allegedly dominant influences job satisfaction on work spirit employees Dolphins Chips Company Malang.

By As'ad, research on job satisfaction is often done. However, the problem of employee satisfaction remains important because it has been proven beneficial in improving employee attitudes and behavior that would benefit the company [5]. The job itself is the view of employees on the job. Following suitability skilled jobs that employees can encourage employees to produce a good performance and increase job satisfaction. Payroll system is also tailored to the skill level of employees, when the opportunities provided by the company are lower than thoseapplied to similar companies can lead to employee dissatisfaction with pay. As well as with colleagues who are a source of job satisfaction for individual employees. The working group with a high degree of proximity tends to cause employees to be more satisfied in the working group. Promotion has a different effect on job satisfaction. Promotion will provide opportunities for personal growth, more responsibility, and increased social status. When the campaign carried out in a fair, expected to provide employee satisfaction to employees [6]. Employees will be satisfied if the assessment work is carried out fairly. Results of Simamora et al., Rehatta, Nurbudiyani and Rahman found that job satisfaction affects work spirit and increased social status $[3,4,15,16]$.

\section{METHOD}

\subsection{Research design}

This research uses explanatory research, which highlights the relationship between variables - variables of research and testing hypotheses that have been formulated. In this type of research should be a hypothesis to test the truth. The hypothesis itself will describe the relationship between several variables or more. From this description, it will be known whether or not the variable correlated with other variables. The survey method used in this study. The approach is a quantitative study, using data from a number as an analytical tool. Data were collected through questionnaires. Using a Likert scale for easy measurement. Relations latent variables and indicators are reflective. Variable Work spirit is reflected by the four indicators that carry out tasks according to the time, the low attendance rate, Labor turnover, Reduced anxiety. Variable Leadership is reflected by the five indicators of ability to foster cooperation and good relations, ability effectiveness, participatory leadership, ability to delegate tasks or time, ability to delegate tasks or authority. Work Environment Variables reflected by two indicators: the physical work environment, non-physical work environment. Job Satisfaction Variables reflected by seven indicators: Contents of work, supervision, organization and management, opportunities to advance, salary, co-worker, job conditions. Ability to delegate tasks or time, the ability to delegate tasks or authority. Work Environment Variables reflected by two indicators: the physical work environment, non-physical work environment. Job Satisfaction Variables reflected by seven indicators: Contents of work, supervision, organization and management, opportunities to advance, salary, co-worker, job conditions. Ability to delegate tasks or time, the ability to delegate tasks or authority. Work Environment Variables reflected by two indicators: the physical work environment, non-physical work environment. Job Satisfaction Variables reflected by seven indicators: Contents of work, supervision, organization and management, opportunities to advance, salary, co-worker, job conditions.

\subsection{Population}

The population in this study is the overall company employees Dolphins Chips Company Malang, amounting to 125 employees.

\subsection{Sampling}

In this study the technique of sampling using non-probability sampling by census, using the population as a whole the number of samples. So respondents drawn amounted to 125 respondents.

\section{RESULT AND DISCUSSION}

\subsection{Testing Instruments}

Table 1 shows the results of the analysis of the validity and reliability of the research instruments. Product moment correlation coefficient values for each indicator study shows the results above 0.3 with a significance level of less than 0001 , it indicates that the item question is able to measure the symptoms studied. Alpha Chronbach value for each variable research is still above 0.6, indicating that the item in question is able to achieve a good level of consistency. 
International Journal of Advances in Scientific Research and Engineering (ijasre), Vol 6 (3), March -2020

Table 1 Composite Validity and Reliability Research Instruments

\begin{tabular}{|c|c|c|c|}
\hline Variables & Item & Product Moment Correlation & Alpha Chronbach \\
\hline \multirow{12}{*}{$\begin{array}{l}\text { Leadership } \\
\text { (X1) }\end{array}$} & X1.1.1 & 0.690 & \multirow{12}{*}{0.871} \\
\hline & $\mathrm{X} 1.1 .2$ & 0.694 & \\
\hline & X1.2.1 & 0.734 & \\
\hline & $\mathrm{X} 1.2 .2$ & 0.612 & \\
\hline & X1.2.3 & 0.713 & \\
\hline & X1.3.1 & 0.666 & \\
\hline & $\mathrm{X} 1.3 .2$ & 0.604 & \\
\hline & X1.3.3 & 0.512 & \\
\hline & X1.4.1 & 0.601 & \\
\hline & $\mathrm{X} 1.4 .2$ & 0,711 & \\
\hline & X1.5.1 & 0,535 & \\
\hline & $\mathrm{X} 1.5 .2$ & 0.671 & \\
\hline \multirow{6}{*}{$\begin{array}{l}\text { Working } \\
\text { Environment (X2) }\end{array}$} & X2.1.1 & 0.683 & \multirow{6}{*}{0.869} \\
\hline & X2.1.2 & 0.804 & \\
\hline & X2.1.3 & 0.789 & \\
\hline & $\mathrm{X} 2.2 .1$ & 0.890 & \\
\hline & X2.2.2 & 0.686 & \\
\hline & $\mathrm{X} 2.2 .3$ & 0.815 & \\
\hline \multirow{14}{*}{$\begin{array}{c}\text { Job satisfaction } \\
\text { (X3) }\end{array}$} & X3.1.1 & 0,531 & \multirow{14}{*}{0.831} \\
\hline & X3.1.2 & 0,646 & \\
\hline & X3.2.1 & 0.628 & \\
\hline & X3.2.2 & 0.665 & \\
\hline & $\mathrm{X} 3.3 .1$ & 0.704 & \\
\hline & X3.3.2 & 0,548 & \\
\hline & X3.4.1 & 0.519 & \\
\hline & X3.4.2 & 0.446 & \\
\hline & X3.5.1 & 0.486 & \\
\hline & X3.5.2 & 0.592 & \\
\hline & X3.6.1 & 0.542 & \\
\hline & X3.6.2 & 0.491 & \\
\hline & X3.7.1 & 0.456 & \\
\hline & X3.7.2 & 0.591 & \\
\hline \multirow{13}{*}{$\begin{array}{l}\text { Work spirit } \\
\text { (Y) }\end{array}$} & Y1.1.1 & 0.754 & \multirow{13}{*}{0.946} \\
\hline & Y1.1.2 & 0.767 & \\
\hline & Y1.1.3 & 0,812 & \\
\hline & Y1.2.2 & 0.854 & \\
\hline & Y1.3.1 & 0.705 & \\
\hline & Y1.3.2 & 0,833 & \\
\hline & Y1.3.3 & 0.839 & \\
\hline & Y1.3.1 & 0.684 & \\
\hline & Y1.3.2 & 0.822 & \\
\hline & Y1.4.1 & 0.766 & \\
\hline & Y1.4.2 & 0.854 & \\
\hline & Y1.4.3 & 0.710 & \\
\hline & Y1.4.4 & 0,836 & \\
\hline
\end{tabular}

Figure 1. Based on the results of multiple regression analysis showed that the greatest regression coefficient of 0.553 namely job satisfaction, job satisfaction this means is a variable that dominant effect on work spirit. Thus the second hypothesis is statistically accepted or tested. 


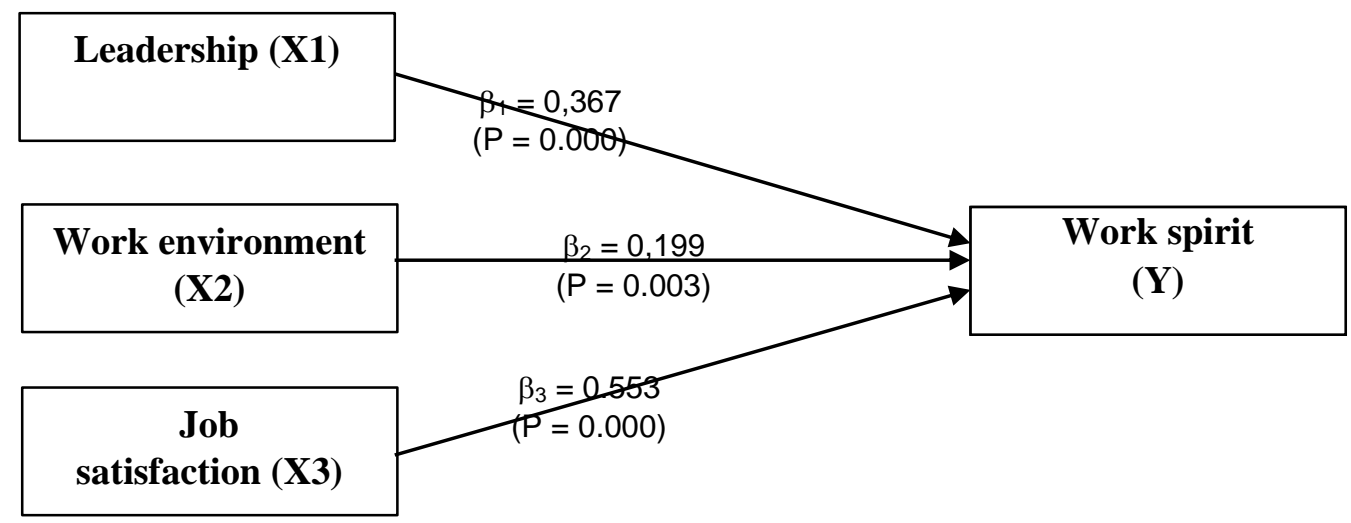

Figure 1 Results Regression analysis

The value of the multiple correlation coefficient (R) of 0.850 indicates a strong relationship between the leadership (X1), work environment (X2), and job satisfaction (X3) together with work spirit (Y). The coefficient of determination (Adjusted R square) of 0.716. The coefficient of determination shall have the meanings that leadership (X1), work environment (X2), and job satisfaction (X3) together to contribute to the work spirit of $71.6 \%$, while the remaining $28.4 \%$ were caused by other variables which is not included in the study.

Table 2 Recapitulation Results of Multiple Linear Regression Analysis

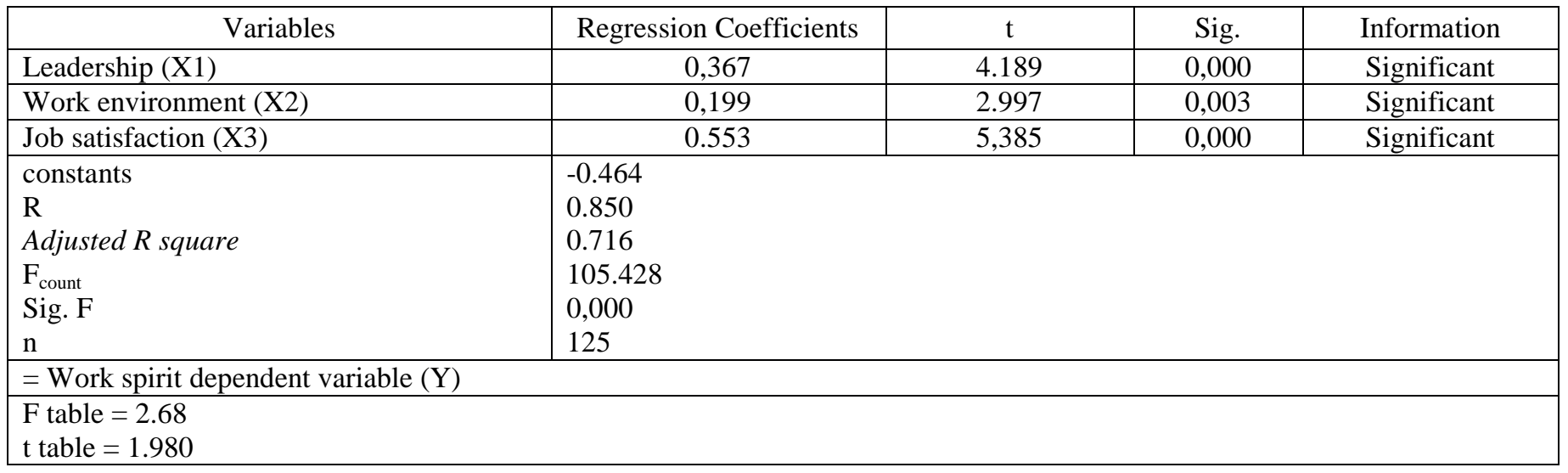

\subsection{Leadership Influence on Work spirit}

Leadership significant effect on work spirit, which means that the better implementation of leadership within the company can improve work spirit. Indicators of leadership that gives the largest contribution to the increase in work spirit that is the ability to foster cooperation and good relations. The results of this study are consistent with Priatna and Ferdiansyah, and Tarlis, which states that the leadership effect on employee work spirit $[11,12]$.

\subsection{Work Environment influence on Work spirit}

Work environment significantly affect work spirit. Indicators work environment can improve work spirit is the physical work environment is reflected in the arrangement of working space can assist in completing the work. It is powered from respondents who agree that the arrangement of the workspace can assist in completing the work. The results of this study are consistent with Anwar, Dwijayani, Nurbudiyani which states that the work environment influence on work spirit $[13,14,15]$.

\subsection{Effect of Job Satisfaction on Work spirit}

Job satisfaction effect on work spirit. Indicators of job satisfaction can improve work spirit is reflected in the organization and management of the company's job description is clear. This is in line with research Simamora et al., Rehatta, Nurbudiyani and Rahman which states that job satisfaction effect on work spirit $[15,4,15,16]$. From these explanations it can be seen that the first hypothesis can be accepted, which means that the independent variables: leadership, work environment and job satisfaction simultaneously significant effect on work spirit.

\subsection{Job Satisfaction of Dominant Influence on work spirit}

Based on the results of multiple regression analysis showed that the greatest regression coefficient value is job satisfaction dominant influential variable by looking at the magnitude of the regression coefficient significant effect on work spirit. The 
independent variables that have the most substantial and significant coefficient is a variable that dominant effect on work spirit. this means the variable job satisfaction is the dominant influence on work spirit. Thus the second hypothesis is statistically accepted or tested.

\section{CONCLUSION AND SUGGESTION}

\subsection{Conclusion}

The company's leadership in Dolphins Chips Company Malang end to realize the objectives related to the mission ideological groups on the values, ideas and aspirations embedded in subordinates. The main thing that encourages job is to carry out tasks according to the time reflected the respondents did not delay the work, while supporting the leadership is the ability to foster cooperation and good relations reflected the ability of a leader to motivate subordinates. Work environment shaped by the physical working environment is reflected in the arrangement of working space can assist in completing the work. Job satisfaction is formed by the content of the work, supervision, organization and management, opportunity to move forward, salary, coworkers, and working conditions.

Leadership, work environment and job satisfaction effect on employee work spirit Dolphins Chips Company Malang, which means that the better implementation of the leadership, supported by a pleasant working environment in completing the work, as well as employee satisfaction at work can boost employee work spirit.

Job satisfaction dominant influence on employee work spirit Dolphins Chips Company Malang. This indicates that under consideration to improve employee work spirit, job satisfaction is made up of the organization and management of the company in the form of a clear job description.

\subsection{Suggestion}

This study is limited to the three variables, namely the variables of leadership, work environment, job satisfaction and one dependent variable that is work spirit. Additionally in this study using multiple linear regression analysis. So to further recommended that researchers use different analysis techniques or add other variables outside variables that have not been examined in this study, can be expected to affect work spirit.

\section{REFERENCES}

1. Susanty, Etty. 2012. Pengaruh Iklim Organisasi Terhadap Kepuasan Kerja dan Komitmen Karyawan Pada Universitas Terbuka. Jurnal Organisasi dan Manajemen, Volume 8, Nomor 2: 121-134.

2. Robbins dan Judge. 2008. Perilaku Organisasi. Edisi Duabelas, Penerbit Salemba Empat: Jakarta.

3. Simamora, Fransisca, Maschasin dan Sri Restuti. 2015. Pengaruh Pelatihan dan Kepuasan Kerja Terhadap Semangat Kerja Karyawan Pada Perum Pegadaian Kantor Wilayah Pekanbaru. Jon FEKON. Volume 2 No. 1: 1-13.

4. Rehatta, Pieter N.R. 2016. Analisis Pengaruh Kepuasan Kerja Dan Komitmen Organisasi Terhadap Semangat Kerja Pegawai Bapedda Provinsi Maluku. Cita Ekonomika, Journal Ekonomi. Vol. X No. 1: 61-68.

5. As'ad, M. 2004. Psikologi Industri, Seri Umum. Sumber Daya Manusia. Edisi 4. Liberty, Yogyakarta.

6. Luthans, F. 2005. Organizational Behavior. Seventh Edition. McGraw-Hill, Inc.,New York.

7. Nitisemito, Alex S. 2010. Manajemen personalia Manajemen Sumber Daya Manusia. Edisi Ketiga. Jakarta : Ghalia Indonesia

8. Moekijat. 2011. Latihan dan Pengembangan Sumber Daya Manusia. Bandar Maju. Bandung

8. Rivai, Veitzhal dan Mulyadi, Deddy. 2012. Kepemimpinan dan Perilaku Organisasi. Jakarta: PT Raja Grafindo Persada

9. Sedarmayanti. 2012. Manajemen Sumber Daya Manusia. Jakarta : Refika Aditama Eresco.

10. Rivai, Veithzal. 2010. Manajemen Sumber Daya Manusia Untuk Perusahaan Dari Teori ke Praktik. Jakarta: Raja Grafindo Persada.

11. Priatna, Angka dan Fariz Ferdiansyah. 2015. Pengaruh Gaya Kepemimpinan Terhadap Semangat Kerja PNS Pada Kementerian Agama Kabupaten Bogor. Jurnal Ilmiah Manajemen Fakultas Ekonomi. Volume 1. No. 1: 6-11.

12. Tarlis, Andi. 2017. Pengaruh Gaya Kepemimpinan Terhadap Semangat Kerja Karyawan Pada Bank Mandiri Cabang Langsa. JII. Volume 2. No. 2: 1-20.

13. Anwar, Hairil. 2013. Pengaruh Lingkungan Kerja Pegawai Terhadap Semangat Kerja Pegawai Kantor Imigrasi Kota Samarinda. e-Journal Ilmu Pemerintahan. Volume 1. No: 1: 348-358.

14. Dwijayani, Henny. 2014. Pengaruh Mutasi dan Lingkungan Kerja Terhadap Semangat Kerja Karyawan Perusahaan Daerah. Jurnal Intake. Vol. 5. Nomor 1: 48 - 57.

15. Nurbudiyani, Iin. 2016. Pengaruh Kepuasan Kerja dan Lingkungan Kerja Terhadap Semangat Kerja Pegawai Universitas Muhammadiyah Palangkaraya. Anterior Jurnal. Volume 16 Nomor 1: 7 - 13.

16. Rahman, Taufik. 2017. Pengaruh Kepuasan Kerja Terhadap Semangat Kerja Karyawan Pada PT. Bangun Nusantara Jaya Makmur (BNJM) Kabupaten Tabalong. Jurnal Ilmu Administrasi Publik dan Bisnis. Vol. 1 No. 1: 124 - 142. 